\title{
THE ANTIBODY RESPONSE TO THE FLAGELLA OF PSEUDOMONAS AERUGINOSA
}

\author{
T. L. Pitt* and D. E. Bradley $\dagger$ \\ ${ }^{*}$ Cross-Infection Reference Laboratory, Central Public Health Laboratory, Colindale Avenue, \\ London, NW9 SHT, and †Department of Zoology, University of Edinburgh, West Mains \\ Road, Edinburgh, EH9 3JT
}

\section{Plate VI}

THE heat-stable somatic antigens of Pseudomonas aeruginosa-the cell-wall lipopolysaccharides-provide the basis of the most widely used methods for the serological typing of this organism (Habs, 1957; Verder and Evans, 1961; Lányi, 1966-67; and Homma et al., 1970). These procedures, in which sera are prepared against boiled or autoclaved organisms, have the disadvantage that some of the groups or "types" defined are rather common and may constitute up to $10-20 \%$ of all strains encountered.

Sera prepared in animals against unheated organisms also contain antibodies against various inadequately defined heat-labile bacterial constituents, but attempts to make use of these for the construction of a serological typing system have given confusing results (Aoki, 1926; Munoz, Scherago and Weaver, 1945; Gaby, 1946; Christie, 1948; Mayr-Harting, 1948; van den Ende, 1952; Matsui, 1959; Verder and Evans, 1961; and Lányi 1970). It seems that an essential preliminary to developing a useful typing system based on heat-labile antigens is to distinguish between the various classes of antigen, such as those of the flagella and the fimbriae (or pili; see, for example, Bradley, 1972 ), and possibly also of the bacterial body.

In the present study, sera were prepared against two strains of $P$. aeruginosa and against variants of them known to be deficient in flagella, fimbriae or both, and the behaviour of these sera was studied in various serological tests. Our first objective was to learn how to recognise the presence of flagellar $(\mathrm{H})$ antibodies and to distinguish them from fimbrial antibodies. This distinction had earlier presented difficulties because we knew of no way of cultivating $P$. aeruginosa in the non-flagellate phase. Microscopic tests for the specific inhibition of motility proved tedious and difficult to interpret, and $P$. aeruginosa will not migrate through semi-solid agar. Robinson (1932) reported that $P$. aeruginosa grows anaerobically in the presence of nitrate, and our preliminary experiments showed that the addition of $0 \cdot 1 \% \mathrm{KNO}_{3}$ to a tube of semisolid agar (Craigie, 1931) permitted motile strains to " grow round" the tube within a few hours. We now describe the use of an inhibition test in nitrate agar to evaluate the specificity of other serological tests for the flagellar antigens of $P$. aeruginosa. 


\section{MATERIALS AND METHODS}

\section{Strains of $P$. aeruginosa}

Strain K (no. ATCC25102) was obtained from the American Type Culture Collection. Mutants of it were $\mathrm{K} / 1 \mathrm{PO}^{-}$, a fimbria-less mutant resistant to phage $\mathrm{PO} 4 ; \mathrm{K}_{3} \mathrm{fla}^{-}$, a non-flagellate mutant and $\mathrm{K} 3 \mathrm{fla}^{-} / \mathrm{PO}^{-}$, a fimbria-less mutant of $\mathrm{K}^{-} \mathrm{fla}^{-}$(Bradley, 1973). Strain PAO1, the $P$. aeruginosa strain-1 wild type (Holloway, 1955), was a gift from Professor B. W. Holloway, Department of Genetics, Monash University, Clayton, Victoria, Australia. Strain PAO1/PO4- was a fimbria-less mutant isolated by Bradley (1973). In these studies it is important to distinguish clearly between the non-fimbriate phenotypic state and the fimbria-less $\left(\mathrm{fim}^{-}\right)$genotype.

\section{Media and methods of culture}

Oxoid Nutrient Broth (no. 2) was used throughout for liquid culture; $1 \%$ (w/v) agar was added for plate culture, and $0.4 \%(\mathrm{w} / \mathrm{v})$ agar (" soft agar ") for motility tests. Sodium nitrate was added to either broth or agar to a final concentration of $0 \cdot 2 \%(\mathrm{w} / \mathrm{v})$. Incubation was for $18 \mathrm{~h}$ at $32^{\circ} \mathrm{C}$ unless otherwise stated.

\section{Solutions}

Saline was $0.85 \% \mathrm{NaCl}$ and formol saline was a 1 in 500 dilution of formaldehyde in this. Sørensen phosphate-buffers at $p \mathrm{H} 7.4$ were used for complement-fixation tests and

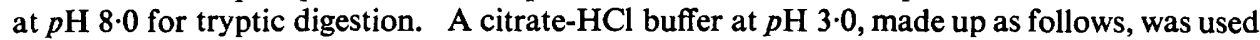
for the dissociation of flagella: solution $A$ was $0.1 \mathrm{M}$ disodium citrate $(21.0 \mathrm{~g}$ of citric acid in $200 \mathrm{ml}$ of $1 \mathrm{~N} \mathrm{NaOH}$ made up to a litre) and solution $B$ was $0.1 \mathrm{~N} \mathrm{HCl} ; 39.9 \mathrm{ml}$ of $A$ was made up to $100 \mathrm{ml}$ with $B$.

\section{Detection of motility}

Microscope-slide tests. Hanging-drop preparations of static 3-h broth cultures were prepared on microscope slides in the conventional manner. The bacteria were left to settle for $c .5 \mathrm{~min}$. and examined microscopically with phase-contrast illumination.

Motility through agar. Single colonies of cultures were stab-inoculated into nitrate soft agar in Craigie tubes. Approximately 6-8 $\mathrm{ml}$ of medium were delivered into a test tube (15 $\mathrm{cm} \times 1.6 \mathrm{~cm})$ containing a piece of glass tubing $(50-\mathrm{mm}$ long) with the bottom cut off obliquely; cultures were seeded into this inner tube which projected above the level of the medium. Motile organisms were selected by subculturing from the top of the medium in the outer tube after incubation at $37^{\circ} \mathrm{C}$ for $18 \mathrm{~h}$.

\section{Preparation of antisera}

Four-hour broth cultures of actively motile cultures were used to seed five 9-cm agarplates which were incubated at $37^{\circ} \mathrm{C}$ for $18 \mathrm{~h}$. The growth was then harvested in formol saline $(10 \mathrm{ml})$, washed once with this and then adjusted by further dilution with formol saline to contain $c .2 \times 10^{9}$ bacteria per ml. The opacity corresponded to that of tube no. 2 (Wellcome Opacity Tubes, Burroughs Wellcome, Beckenham, Kent).

Rabbits were given six injections of this vaccine at 3-5-day intervals. The first four doses $(0.25 \mathrm{ml}, 0.5 \mathrm{ml}, 1.0 \mathrm{ml}$ and $1.5 \mathrm{ml}$ respectively) were given subcutaneously, and the last two doses-both of $2.0 \mathrm{ml}$-intravenously. The animals were bled at intervals and the serum was separated and clarified by centrifugation. Merthiolate at a final concentration of 1 in $5000(\mathrm{w} / \mathrm{v})$ was added as a preservative before the serum was dispensed in $5-\mathrm{ml}$ volumes and stored at $-20^{\circ} \mathrm{C}$.

Absorption of sera. Cells of the absorbing strain harvested from ten 9-cm agar plates were deposited by centrifugation at $10,000 \mathrm{~g}$ for $30 \mathrm{~min}$. Suspensions to be used for the removal of anti-O antibodies were boiled for $2 \frac{1}{2} \mathrm{~h}$ before centrifugation; those used to 
absorb $\mathrm{H}$ antibodies were formolised as described above. To absorb an antiserum, $1 \mathrm{ml}$ of packed cells was thoroughly mixed with an equal volume of serum, incubated at $37^{\circ} \mathrm{C}$ for $2 \mathrm{~h}$, and left for a further $3 \mathrm{~h}$ at $4^{\circ} \mathrm{C}$. The bacteria were removed by centrifugation, and the serum was then passed through a membrane filter.

\section{Agglutination tests}

The overnight growth from an agar plate or slope was suspended in approximately $5 \mathrm{ml}$ of formol saline. The opacity was adjusted by dilution to correspond to opacity tube no. 2 . Agglutination tests were performed by mixing $0 \cdot 3-\mathrm{ml}$ volumes of standardised bacterial suspension with equal volumes of doubling dilutions of serum in Dreyer's tubes. A control tube of saline plus suspension was included. The tests were incubated at $50^{\circ} \mathrm{C}$ for $2 \mathrm{~h}$ and read with a $\times 2$ magnifying lens while obliquely illuminated.

Effect of various agents on flagellar agglutination. Portions of washed-cell suspensions were treated at $37^{\circ} \mathrm{C}$ for $2 \mathrm{~h}$ with crystalline trypsin (Difco) in phosphate buffer, $p \mathrm{H} \mathrm{8.0}$, at final concentrations of trypsin of 2 to $40 \mathrm{mg}$ per $\mathrm{ml}$. The enzyme was removed by washing the cells twice in saline before resuspending them for agglutination tests. The same procedure was adopted for both acid and alcohol; hydrochloric acid and ethyl alcohol were used in concentrations of $0.01 \mathrm{M}-1 \mathrm{M}$ and $10-100 \%(\mathrm{v} / \mathrm{v})$ respectively in distilled water. The effect of heat was studied by incubating a formolised suspension for $15 \mathrm{~min}$. at temperatures of $40^{\circ} \mathrm{C}$ to $90^{\circ} \mathrm{C}$ in $5^{\circ} \mathrm{C}$ steps.

\section{Motility-inhibition tests}

Microscope-slide method. Volumes $(0.2 \mathrm{ml})$ of doubling dilutions of antiserum were mixed in tubes with an equal volume of a 3-h nitrate-broth culture of the test organism. Loopfuls of each mixture were transferred to microscope slides, sealed with Vaseline under cover slips, and left for $25 \mathrm{~min}$. at room temperature. Following this, the slides were examined microscopically with phase-contrast illumination and the ratio of motile to non-motile cells was counted at a magnification of $\times 400$.

Inhibition of motility through agar. Tubes $(10 \mathrm{~cm} \times 0.75 \mathrm{~cm})$ were filled to a depth of $7 \mathrm{~cm}$ with dilutions of serum in nitrate soft-agar and stab-inoculated to a depth of $1 \mathrm{~cm}$ with the appropriate strain. The tests were incubated overnight. The highest dilution of serum that inhibited the migration of the organism, observed by the absence of gas bubbles and opacity in the medium, was termed the immobilisation titre of the serum.

\section{Complement-fixation tests}

An antigen for complement-fixing tests was prepared as follows. Bacteria were harvested from ten $15-\mathrm{cm}$ agar plates in formol saline and the suspensions were homogenised $(75-\mathrm{ml}$ volumes) at room temperature for $4 \mathrm{~min}$. at top speed in an Atomix (Measuring and Scientific Equipment Ltd, Crawley, Sussex) with a chamber capacity of $200 \mathrm{ml}$. The cells were removed by centrifugation twice at $16,000 \mathrm{~g}$ for $20 \mathrm{~min}$. Flagella and other small bodies were deposited by centrifugation at $42,000 \mathrm{~g}$ for $2 \mathrm{~h}$ in a Spinco Model $\mathrm{L}$ preparative ultra-centrifuge. The

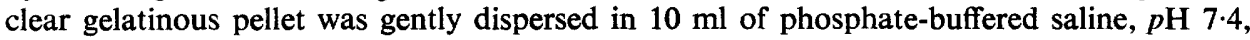
and recentrifuged at $42,000 \mathrm{~g}$ for a further $2 \mathrm{~h}$. The final deposit was dispersed in $1.5 \mathrm{ml}$ of buffer, and checked for "purity" on the electron microscope.

The complement-fixation tests were performed by the method of Bradstreet and Taylor (1962) with overnight fixation at $4^{\circ} \mathrm{C}$ and a complement dose of three times the minimum haemolytic dose. After the addition of sensitised red cells, the tests were incubated at $37^{\circ} \mathrm{C}$ for $30 \mathrm{~min}$. with intermittent shaking and then held for $2 \mathrm{~h}$ at $4^{\circ} \mathrm{C}$; the results were then recorded.

\section{RESULTS}

The results of motility tests on the various strains of $P$. aeruginosa, as determined by the microscope-slide test and the nitrate-agar test, are given in 
table I. In the latter test, growth of the organism and the presence of nitrogen gas bubbles throughout the medium in the outer part of the Craigie tube was considered evidence of motility.

\section{Agglutination tests with the absorbed antisera}

Antisera prepared against the flagellate strains $\mathrm{K}, \mathrm{K} / 1 \mathrm{PO} 4-$, PAO1 and PAO1/PO4 - were tested by the tube-agglutination method with all members of the $\mathrm{K}$ series and the two PAOl strains, after removal of anti-O antibodies by absorption with boiled homologous cells. The $\mathrm{K}$ and the $\mathrm{K} / 1 \mathrm{PO} 4$ - antisera were then absorbed with both flagellate and non-flagellate mutants, and the PAO1 antiserum was absorbed with strain PAO1/PO4 -

The results of agglutination tests (table II) show that high titres $(>5000)$ were obtained only with the flagellate strains, and that high-titre antibody was removed by absorption with homologous flagellate but not with homologous non-flagellate variants. Low-titre agglutination (320) of the non-flagellate suspension of strain $\mathrm{K} 3 \mathrm{fla}$ - by anti-K serum was observed. As this was completely removed (titre $<20$ ) by absorption with the fimbriate but non-flagellate homologous strain $\mathrm{K} 3 \mathrm{fla}-$-, but not by the fimbria-less $\left(\mathrm{fim}^{-}\right.$) strains $\mathrm{K} / 1 \mathrm{PO} 4$ and $\mathrm{K} 3 \mathrm{fla}-/ \mathrm{PO} 4$-, it appears to be due to anti-fimbrial antibody. The results of absorption on the very low-titre antibody against $\mathrm{K} 3 \mathrm{fla}$-in the anti-K/1PO4 serum were equivocal.

The flagellar agglutination appeared "fluffy", not unlike tufts of cotton wool. The titres are expressed as the last serum dilution showing easily visible agglutination. The titres did not increase after incubation in the cold, but appeared clearer if treated in this manner.

\section{Effect of agents on $H$ agglutination}

Exposure of flagellate suspensions to $0.01 \mathrm{M} \mathrm{HCl}$ and $40 \%$ ethyl alcohol rendered the cultures inagglutinable by the homologous antiserum. Cells

TABLE I

Presence of flagella and fimbriae in two strains of Pseudomonas aeruginosa and their variants, and results of motility tests on them

\begin{tabular}{|c|c|c|c|c|}
\hline \multirow{2}{*}{ Strain } & \multicolumn{2}{|c|}{ Presence of } & \multicolumn{2}{|c|}{ Motility demonstrated } \\
\hline & fimbria(e) & flagellum & $\begin{array}{c}\text { by microscopic } \\
\text { examination }\end{array}$ & in agar \\
\hline $\begin{array}{l}\text { K } \\
\text { K/1PO4- } \\
\text { K3fla- } \\
\text { K3fla } \\
\text { PAO1 } \\
\text { PAO4- } \\
\text { PAO1/PO4- }\end{array}$ & $\begin{array}{l}\frac{+}{+} \\
\frac{+}{+} \\
\frac{+}{-}\end{array}$ & $\begin{array}{l}+ \\
+ \\
- \\
+ \\
+\end{array}$ & $\begin{array}{l}+ \\
+ \\
+ \\
+ \\
+ \\
+\end{array}$ & $\begin{array}{l}+ \\
\pm \\
\pm \\
+ \\
+\end{array}$ \\
\hline
\end{tabular}


suspended in buffer at $p \mathrm{H} 3.0$ were also not agglutinated. After exposure of aqueous suspensions to heat at $65^{\circ} \mathrm{C}$ for $15 \mathrm{~min}$., their agglutinability was reduced, and no agglutination occurred after exposure of suspensions to temperatures of $70^{\circ} \mathrm{C}$ or above.

\section{Antibody response to $O$ and $H$ antigen}

Test bleedings were taken from rabbits at frequent intervals throughout courses of immunisation. The anti-O antibody was measured by agglutination tests with boiled suspensions of the vaccine strain, and anti- $\mathrm{H}$ antibody with formolised suspensions of the same strain. The titres are plotted against time, and a typical result is shown in fig. 1. The graph shows the agglutination titres of serum against the non-fimbriate strain $\mathrm{K} / 1 \mathrm{PO} 4-$. The peak of $\mathrm{H}$ antibody titre was reached on the 20th day and there was a slight subsequent fall. Despite continued injections, the anti-O titre fell sharply by the 3 rd week and had become negligible by the 4th week. This sequence of events is, in our experience, characteristic of the $\mathrm{O}$-antibody response to $P$. aeruginosa.

\section{Motility-inhibition tests with absorbed sera}

Motile cultures in nitrate broth were mixed with dilutions of the appropriate serum and examined under the microscope for the inhibition of motility. An $80 \%$ loss of motility in comparison with a control was taken as the end point and the serum dilution giving the effect was termed the inhibition titre of the serum. The cultures were also seeded into nitrate soft-agar containing various dilutions of antiserum. The last serum dilution to immobilise the culture completely was taken as the immobilisation titre.

Titres of inhibition of motility in liquid media were 5 to 10 -fold higher than

TABLE II

Results of agglutination tests with antisera prepared against flagellate strains of Pseudomonas aeruginosa before and after absorption with flagellate and non-flagellate variants

\begin{tabular}{|c|c|c|c|c|c|c|}
\hline \multirow{2}{*}{$\begin{array}{l}\text { Antiserum prepared } \\
\text { against strain* }\end{array}$} & \multicolumn{6}{|c|}{$\begin{array}{l}\text { Titres of agglutination produced by the stated antiserum } \\
\text { with bacterial suspension }\end{array}$} \\
\hline & $\mathbf{K}$ & $\mathrm{K} / 1 \mathrm{PO}^{-}$ & $\mathrm{K}^{2} \mathrm{fla}^{-}$ & $\mathrm{K} 3 \mathrm{fla}^{-} / \mathrm{PO}^{-}$ & PAO1 & PAO1/PO4- \\
\hline $\begin{array}{l}\text { K } \\
\text { K/1PO4- } \\
\text { K abs. K/1PO4- } \\
\text { K abs. K3fia } 4^{-} \\
\text {K abs. K3fia }-/ \mathrm{PO}^{-} \\
\text {K/1PO4 abs. K3fla } \\
\text { K/1PO4 abs. K3fla }{ }^{-} / \mathrm{PO}^{-} \\
\text {PAO1 } \\
\text { PAO1 abs. PAO1/PO4- } \\
\text { PAO1/PO4- }\end{array}$ & $\begin{array}{r}5120 \\
10240 \\
<20 \\
5120 \\
5120 \\
10240 \\
10240 \\
<20 \\
\dddot{20}\end{array}$ & $\begin{array}{r}5120 \\
10240 \\
<20 \\
5120 \\
5120 \\
10240 \\
10240 \\
<20 \\
\dddot{*} \\
<20\end{array}$ & $\begin{array}{r}320 \\
40 \\
160 \\
<20 \\
320 \\
<20 \\
<20 \\
<20 \\
\dddot{<20}\end{array}$ & $\begin{array}{r}40 \\
40 \\
<20 \\
<20 \\
<20 \\
<20 \\
<20 \\
<20 \\
\hdashline 20\end{array}$ & $\begin{array}{c}<20 \\
<20 \\
\ldots \dagger \\
\ldots \\
\ldots \\
\ldots \\
10240 \\
160 \\
10240\end{array}$ & $\begin{array}{c}<20 \\
<20 \\
\cdots \\
\ldots \\
\cdots \\
\ldots \\
10240 \\
40 \\
10240\end{array}$ \\
\hline
\end{tabular}


the corresponding titres of agglutination (table III). Some non-specific inhibition of motility was observed, but only at serum concentrations 100 times greater than those required for specific inhibition. Immobilisation in agar (fig. 2) occurred at titres of the same order as the agglutination titres and appeared to be entirely specific.

\section{Complement-fixation tests}

Preparations of the flagellate and fimbriate strains K and PAO1 were used as antigens in the complement-fixation (CF) test; results are given in table IV. Very high and apparently $\mathrm{H}$-specific $\mathrm{CF}$ titres were obtained with preparations deposited by centrifugation at $42,000 \mathrm{~g}$ and resuspended in a small volume of buffer solution (see Methods). CF titres with absorbed antiserum believed to contain antibody against fimbriae but not against flagella (anti-K abs K1/1PO4 -) were low.

Titres of less than 100 were obtained with broth-culture supernates, but slightly better titres (160-1280) were given by supernates of blended broth and

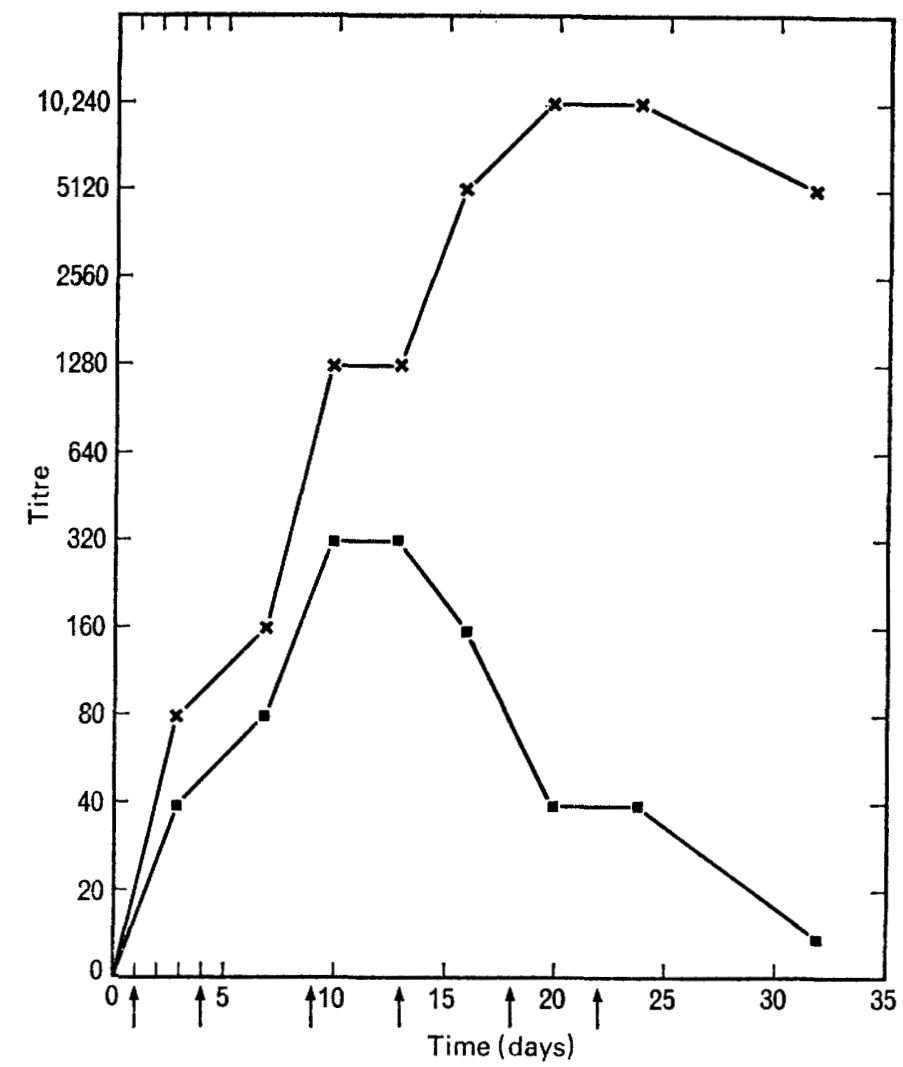

Fig. 1.-The agglutination titres of sera against strain $\mathrm{K} / 1 \mathrm{PO}-\mathrm{a}$ fimbria-less (fim ${ }^{-}$) or pilus-less mutant - with boiled ( - $)$ and formolised $(x-\times)$ cells of the homologous strain; $\uparrow=$ vaccine given on these days. 
ANtibodies to flagella of P. AERUGiNos A

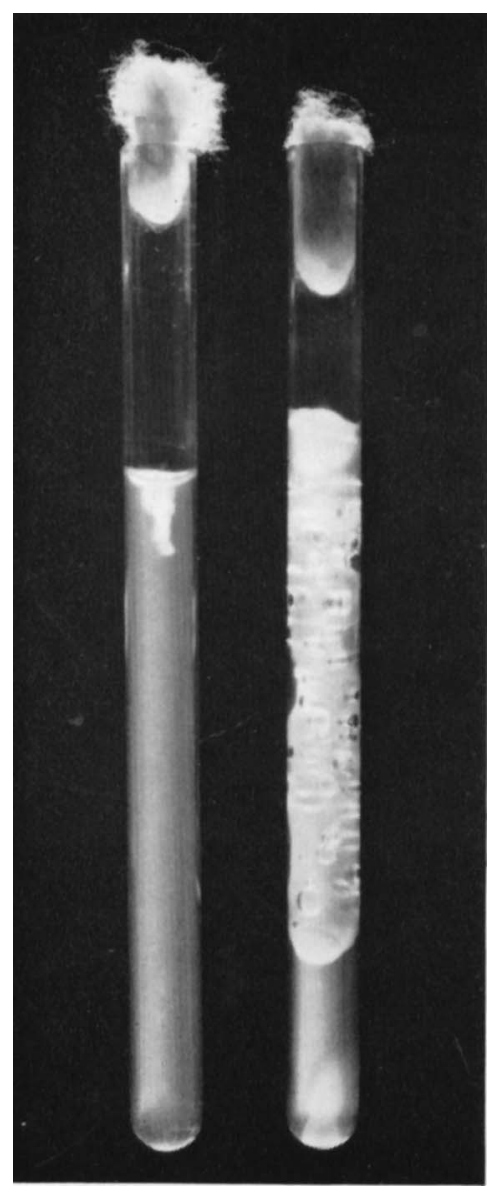

FIG. 2.-Motile strains $\mathrm{K}$ (left) and PAO1 (right) in nitrate-agar medium containing antiserum against strain K. The homologous serum prevented motility as shown by the lack of opacity and the absence of bubbles of gas throughout the medium. 
TABLE III

Inhibition of motility by anti-flagellar antisera

\begin{tabular}{|c|c|c|c|c|c|}
\hline \multirow{2}{*}{$\begin{array}{l}\text { Antiserum prepared } \\
\text { against strain* }\end{array}$} & \multirow{2}{*}{ Tested in } & \multicolumn{4}{|c|}{$\begin{array}{c}\text { Titre of inhibition of motility by the stated } \\
\text { antiserum with strain }\end{array}$} \\
\hline & & $\mathbf{K}$ & $\mathrm{K} / 1 \mathrm{PO}^{-}{ }^{-}$ & PAO1 & $\mathrm{PAO}_{/ \mathrm{PO}^{-}}$ \\
\hline $\mathbf{K}$ & $\begin{array}{l}\text { broth } \\
\text { agar }\end{array}$ & $\begin{array}{r}51,200 \\
6400\end{array}$ & $\begin{array}{r}25,600 \\
6400\end{array}$ & $\ldots+$ & $\cdots$ \\
\hline $\mathrm{K} / 1 \mathrm{PO}^{-}$ & $\begin{array}{l}\text { broth } \\
\text { agar }\end{array}$ & $\begin{array}{r}51,200 \\
6400\end{array}$ & $\begin{array}{r}25,600 \\
6400\end{array}$ & $\begin{array}{l}\cdots \\
\cdots\end{array}$ & $\cdots$ \\
\hline $\mathrm{K}$ abs. $\mathrm{K} / \mathbf{1 P O}^{-}$ & $\begin{array}{l}\text { broth } \\
\text { agar }\end{array}$ & $\begin{array}{r}160 \\
<20\end{array}$ & $\begin{array}{r}80 \\
<20\end{array}$ & $\cdots$ & $\ldots$ \\
\hline $\mathrm{K}$ abs. $\mathrm{K}^{3} \mathrm{fla}^{-}$ & $\begin{array}{l}\text { broth } \\
\text { agar }\end{array}$ & $\begin{array}{r}25,600 \\
6400\end{array}$ & $\begin{array}{r}25,600 \\
6400\end{array}$ & $\cdots$ & $\cdots$ \\
\hline PAO1 & $\begin{array}{l}\text { broth } \\
\text { agar }\end{array}$ & $\cdots$ & $\cdots$ & $\begin{array}{r}102,000 \\
10,240\end{array}$ & $\begin{array}{l}51,200 \\
10,240\end{array}$ \\
\hline PAO1 abs. PAO1/PO4- & $\begin{array}{l}\text { broth } \\
\text { agar }\end{array}$ & $\cdots$ & $\cdots$ & $\begin{array}{r}160 \\
<20\end{array}$ & $\begin{array}{r}160 \\
<20\end{array}$ \\
\hline
\end{tabular}

* abs. = Absorbed with. $\quad \dagger \ldots=$ Not done.

agar cultures. However, these titres were nearly 100 -fold less than those with the concentrated (deposited) antigen.

\section{Discussion}

An exclusively serological typing system for $P$. aeruginosa, if sufficiently discriminatory, would be of great value in epidemiological studies. Some investigators (Christie, 1948; Matsui, 1959; Verder and Evans, 1961) have recognised several heat-labile antigens, but others have failed to differentiate

\section{TABLE IV}

Complement-fixing (CF) titres of antisera in tests with preparations of Pseudomonas aeruginosa cells concentrated by centrifugation at $42,000 \mathrm{~g}$

\begin{tabular}{l|cc}
\hline $\begin{array}{c}\text { Antiserum prepared } \\
\text { against strain* }\end{array}$ & $\begin{array}{c}\text { CF titre of the stated antiserum } \\
\text { in tests with a concentrated } \\
\text { preparation of strain }\end{array}$ \\
\hline K & $\overbrace{}^{\mathbf{K}}$ & PAO1 \\
K/1PO4- & 76,800 & 80 \\
K abs. K/1PO4- & 76,800 & 80 \\
K abs. K3ffa- & 80 & $<20$ \\
PAO1 & 38,400 & 20 \\
PAO1 abs: PAO1/PO4- & 20 & 38,400 \\
\hline
\end{tabular}

- abs. = Absorbed with. 
between $\mathrm{O}$ and $\mathrm{H}$ agglutination or did not report such findings in their publications. The present investigation has attempted to distinguish the flagellar antigens from other heat-labile antigens and to study the specific antibodies formed to flagella.

It was relatively simple to prepare specific $H$ antisera provided that (1) actively motile cells are selected for the vaccine, and (2) the existence of fimbriae is recognised and their effects eliminated. The passage of bacteria through semi-solid media enhances the selection of actively motile cells, but passage of the strictly aerobic $P$. aeruginosa through conventional semisolid media proves difficult. The utilisation of nitrate as an alternative terminal electron-acceptor (Stanier, Palleroni and Doudoroff, 1966) enables $P$. aeruginosa to grow well in the absence of oxygen. We made use of this principle for the demonstration of motility and in the development of a test to assess the immobilisation of the bacteria by specific flagellar antibody.

Most strains of $P$. aeruginosa are fimbriate and these structures are known to be heat-labile (Weiss and Raj, 1972). The fimbriae are antigenic and serologically heterogeneous (Bradley and Pitt, unpublished) but we know of no means of cultivating fimbriate strains of $P$. aeruginosa in the non-fimbriate phase. Flagellar antisera can be prepared readily if fimbria-less (fim ${ }^{-}$) mutants are used as vaccine strains or if antisera against wild-type strains are absorbed with homologous non-motile variants. Non-fimbriate mutants can be readily selected by their resistance to fimbria-specific "pilus phages" (Bradley and Pitt, 1974). There is little need to remove $\mathrm{O}$ antibodies from $\mathrm{H}$ antisera, because anti-O titres are usually negligible when the peak of the anti-H titre is reached.

However, in the absence of fimbria-less or non-flagellate mutants, $\mathrm{H}$ antigens may be accurately detected by the demonstration of specific immobilisation in agar. A comparison of the titres obtained by this method with those given by agglutination tests with formolised suspensions suggests that high titres of agglutinating activity are attributable exclusively to $\mathrm{H}$ antibody. If so, agglutination tests with suitably diluted antisera may prove to be an easy and reliable means of H-typing. It will be necessary, however, to show that the agglutination reactions of the diluted typing serum with the homologous vaccine strain can be matched by the results of a specific immobilisation test. The high sensitivity of the complement-fixation test suggests that this may prove to be a useful means of detecting small differences between closely related flagellar antigens.

Some incidental information concerning the retractile nature of the fimbriae of $P$. aeruginosa has been obtained (Bradley, 1972). It has been found (Bradley, unpublished) that, in addition to phage adsorption, the exposure of fimbriae to certain fixatives including formaldehyde causes the filaments to retract into the cell and disappear. One would therefore expect that antisera prepared against formalin-fixed fimbriate bacteria would show no evidence of antifimbrial antibodies in agglutination tests with formolised suspensions of the corresponding non-flagellate, fimbriate mutants. However, some of our present findings (table III) show that a vaccine containing formolised cells of 
strain $\mathrm{K}$ produced a serum that has a significant amount of agglutinating activity in tests with the non-flagellate mutant $\mathrm{K} 3 \mathrm{fla}^{-}(320)$. This shows that any loss of fimbriae by formaldehyde-triggered retraction is only partial and demonstrates the necessity of removing anti-fimbrial antibodies from a serum prepared with a fimbriate strain or of using the serum at a dilution well above the fimbrial-antibody level.

Bacterial flagella are known to be dissociated by a variety of agents including acid and heat (Iino, 1969). Our results indicate that these agents also appear to dissociate the flagella of $P$. aeruginosa. Bradley (1973) used the antibodylabelling technique designed for electron microscopy (Lawn, 1967) to show that flagellar antibodies against strain $\mathrm{K}$ were absorbed only to the flagella of strain $\mathrm{K}$ and not to the flagella of strain PAO1. As we have seen in the present study, the results of agglutination, immobilisation and complement-fixation tests confirm that the flagella of these strains are serologically different. We have now identified at least four different flagellar antigens by these methods and we hope to demonstrate that this provides a basis for a combined $\mathrm{H}$ - and O-typing system for $P$. aeruginosa.

\section{SUMMARY}

Mutants lacking flagella or fimbriae (pili) or both were used for the preparation and absorption of rabbit antisera against the flagella of Pseudomonas aeruginosa. The results of agglutination, immobilisation and complementfixation tests indicate that the antisera obtained are specific for flagella.

The incorporation of nitrate into semi-solid agar for motility and immobilisation tests was found useful for the selection of actively motile cells and for the demonstration of specific antibody to flagella.

\section{REFERENCES}

Aokı, K. 1926. Agglutinatorische Einteilung von Pyocyaneus-Bazillen welche bei verschiedenen Menschenerkrankungen nachgeweisen wurden. Zentbl. Bakt. ParasitKde, I. Abt. Orig., 98, 186.

Bradley, D. E. 1972. Stimulation of pilus formation in Pseudomonas aeruginosa RNA bacteriophage adsorption. Biochem. biophys. Res. Commun., 47, 1080.

BRADLey, D. E. 1973. Basic characterisation of a Pseudomonas aeruginosa pilus-dependent bacteriophage with a long noncontractile tail. J. Virol., 12, 1139.

Bradley, D. E. ANd PItT, T. L. 1974. Pilus-dependence of four Pseudomonas aeruginosa bacteriophages with noncontractile tails. J. gen. Virol., $23,1$.

Bradstreet, C. M. P. AND TAYLOR, C. E. D. 1962. Technique of complement-fixation test applicable to the diagnosis of virus diseases. Mon. Bull Minist. Hlth, 21, 96.

Christie, R. 1948. Observations on the biochemical and serological characteristics of Pseudomonas pyocyanea. Aust. J. exp. Biol. med. Sci., 26, 425.

Craigie, J. 1931. Studies on the serological reactions of the flagella of $B$. typhosus. $J$. Immun., 21, 417.

ENDE, M. VAN DEN 1952. Observations on the antigenic structure of Pseudomonas aeruginosa. J. Hyg., Camb., 50, 405.

GABY, W. L. 1946. A study of the dissociative behaviour of Pseudomonas aeruginosa. J. Bact., 51, 217. 
HaBS, I. 1957. Untersuchungen über die O-Antigene von Pseudomonas aeruginosa. Z. Hyg. InfektKrankh., 144, 218.

Holloway, B. W. 1955. Genetic recombination in Pseudomonas aeruginosa. J. gen. Microbiol., 13, 572.

Homma, J. Y., Kim, K. S., Yamada, H., Ito, M., Shionoya, H. and Kawabe, Y. 1970. Serological typing of Pseudomonas aeruginosa and its cross-infection. Jap. J. exp. Med., 40, 347.

IINo, T. 1969. Genetics and chemistry of bacterial flagella. Bact. Rev., 33, 454.

LÁNYI, B. 1966-67. Serological properties of Pseudomonas aeruginosa. I. Group-specific somatic antigens. Acta. microbiol. hung., 13, 295.

LÁnYI, B. 1970. Serological properties of Pseudomonas aeruginosa. II. Type-specific thermolabile (flagellar) antigens. Acta. microbiol. hung., $17,35$.

LAWN, A. M. 1967. Simple immunological labelling method for electron microscopy and its application to the study of filamentous appendages of bacteria. Nature, Lond., 214, 1151.

Matsui, N. 1959. A serological study of Pseudomonas aeruginosa. J. Kansai. med. Sch., 11, 287.

Mayr-Harting, A. 1948. The serology of Pseudomonas pyocyanea. J. gen. Microbiol., $2,31$.

Munoz, J., Scherago, M. and Weaver, R. H. 1945. A serological study of the members of the Pseudomonas genus. J. Bact., 49, 524.

Robinson, G. L. 1932. The growth of B. pyocyaneus in synthetic media. Br. J. exp. Path., $13,310$.

Stanier, R. Y., Palleroni, N. J. ANd Doudoroff, M. 1966. The aerobic pseudomonads: a taxonomic study. J. gen. Microbiol., 43, 159.

Verder, E. AND Evans, J. 1961. A proposed antigenic schema for the identification of strains of Pseudomonas aeruginosa. J. infect. Dis., 109, 183.

Werss, R. J. and RaJ, H. D. 1972. The structure and isolation of pili (fimbriae) of Pseudomonas aeruginosa. Aust. J. exp. Biol. med. Sci., 50, 559. 